\title{
Towards an increase of flash flood geomorphic effects due to gravel mining and ground subsidence in Nogalte stream (Murcia, SE Spain)
}

\author{
Jose Antonio Ortega-Becerril ${ }^{1}$, Guillermina Garzón ${ }^{2}$, Marta Béjar-Pizarro ${ }^{3}$, and Jose Jesús Martínez-Díaz ${ }^{2,4}$ \\ ${ }^{1}$ Dpto. de Geología y Geoquímica, Facultad Ciencias, Universidad Autónoma de Madrid, 28049 Madrid, Spain \\ ${ }^{2}$ Dpto. Geodinámica, Facultad de Geología, Universidad Complutense de Madrid, 28040 Madrid, Spain \\ ${ }^{3}$ Geohazards InSAR laboratory and modeling group, Instituto Geológico y Minero de España (IGME), 28003 Madrid, Spain \\ ${ }^{4}$ Instituto de Geociencias (UCM, CSIC), 28040 Madrid, Spain
}

Correspondence to: Jose Antonio Ortega-Becerril (j.ortega@uam.es)

Received: 20 April 2016 - Published in Nat. Hazards Earth Syst. Sci. Discuss.: 25 April 2016

Revised: 15 September 2016 - Accepted: 5 October 2016 - Published: 24 October 2016

\begin{abstract}
Transition from endorheic alluvial fan environments to well-channelized fluvial systems in natural conditions may occur in response to base-level fluctuations. However, human-induced changes in semi-arid regions can also be responsible for similar unforeseen modifications. Our results confirm that in-channel gravel mining and aquifer overexploitation over the last 50 years in the case study area have changed the natural stability of the Nogalte stream and, as a result, its geomorphic parameters including channel depth and longitudinal profile have begun to adapt to the new situation. Using interferometric synthetic aperture radar (InSAR) data we obtain maximum values for ground subsidence in the Upper Guadalentín Basin of $\sim 10 \mathrm{~cm} \mathrm{yr}^{-1}$ for the period 2003-2010. In this context of a lowered base level, the river is changing its natural flood model to a more powerful one. A comparison of the 1973 flood event, the most dramatic flood event ever recorded in the area, with the 2012 event, where there was a similar discharge but a sediment load deficit, reveals greater changes and a new flooding pattern and extension. In-channel gravel mining may be responsible for significant local changes in channel incision and profile. This, together with the collateral effects of aquifer overexploitation, can favour increased river velocity and stream power, which intensify the consequences of the flooding. The results obtained here clearly demonstrate an existing transition from the former alluvial pattern to a confined fluvial trend, which may become more pronounced in the future due to the time lag between the drop in aquifer level and ground subsidence,
\end{abstract}

and introduce a new scenario to be taken into consideration in future natural hazard planning in this area.

\section{Introduction}

The high potential shown by ephemeral rivers in semi-arid areas to cause geomorphic channel changes and devastating flood activity is due to their intermittent spatial/temporal occurrence. In Europe, $40 \%$ of flood casualties between 1950 and 2006 were related to flash floods (Barredo, 2007). For nearly the same period, in Spain the number of human losses increased from 110 due to permanent floods to 1363 in torrential watersheds (Ayala-Carcedo and Olcina, 2002). These flash flood events affect broader areas and last longer in the Mediterranean than in continental regions, and are expected to increase with global warming (Marchi et al., 2010).

Several ephemeral streams in southeastern (SE) Spain including the Guadalentin River and Nogalte stream have been the subject of many previous studies due to their powerful flash floods, catastrophic rainfall mechanisms and related hazards (e.g. Navarro-Hervás, 1985; Hooke and Mant, 2000; Lopez-Bermúdez et al., 2002; Bull et al., 1999; Hooke et al., 2005; Ortega et al., 2009). However, their flood dynamics and geomorphological impacts have not been previously studied in detail (Gil Meseguer et al., 2012). In particular, the significance of load discharge has been ignored in flood 
prediction and routing (Poesen and Hooke, 1997) due to the lack of records of in-flow sediment concentration.

Despite the low total annual rainfall, intense rainstorm episodes in SE Spain are usually followed by changes in channel position, river banks and longitudinal stream profiles (Conesa-García, 1995). These transformations are mainly produced by high-intensity convective rainstorms of $-500 \mathrm{~mm} \mathrm{day}^{-1}$ rainfall, with up to $200 \mathrm{~mm} \mathrm{~h}^{-1}$ during a $\sim 15$ min peak, which can cause critical floods with a return period of only 7-11 years (Bull et al., 1999). ConesaGarcía (1995) states that these rainstorms generate critical erosive and depositional effects due to the arid environmental conditions, and that even during smaller events a large amount of sediment may be mobilized. These effects in ephemeral streams are related to both geomorphologic and anthropogenic factors.

This case study focuses on the stream and fan of the Nogalte Rambla (ephemeral or dryland stream), which has provided one of the most important examples of flash flood power in SE Spain in recent years. The catastrophic 1973 event destroyed new developments located on the rambla floodplain in the village of Puerto Lumbreras, with a death toll of 86 and the destruction of 120 houses. Immediately downstream, however, the floodwaters spread out over the alluvial fan and did not reach the distal fan outflow. Most studies (e.g. Heras, 1973; Navarro-Hervás, 1985; ConesaGarcía, 1995; López-Bermudez et al., 2002; Gómez-Espín, 2004) determined that the 1973 event should be considered exceptional in terms of return period ( $\sim 500$ years $)$.

A new event, with lower precipitation than the 1973 event but characterized by similar discharge, occurred on 28 October 2012. Despite its smaller impact on the Nogalte upper basin and Puerto Lumbreras village, it produced greater damage along the distal fan area. The extent of the flooded area in 2012 was $116 \mathrm{~km}^{2}$, much greater than in the 1973 event, and a week later $24 \mathrm{~km}^{2}$ was still under water (Gil Meseguer et al., 2012).

A post-flood field survey and record of the flood effects allowed us to recognize the resulting hydrodynamic and morphosedimentary features in the Nogalte fan and surrounding areas. Important differences were observed between the flood behaviour and its subsequent effects in the 1973 and the 2012 events. These significant changes in the extent and distribution of flooded areas, as well as in the erosional and depositional results, led us to analyse why this flooding pattern was modified.

Drastic land use modifications and intense anthropic development have taken place in the area over the last 3040 years. One of the human-induced changes with the greatest impact was the shift to intensive irrigation agriculture, which has led to important aquifer overexploitation. Some recent studies highlight the significant land subsidence occurring in the Guadalentin Basin due to groundwater overexploitation (González and Fernández, 2011; Rigo et al., 2013).
Extensive in-channel gravel mining is another anthropic factor impacting stream changes.

The main purpose of this paper is to evaluate the relative importance of these factors and identify to what extent they are responsible for the recently detected flood behaviour leading to a modified stream flooding model.

We considered three working hypotheses. (1) Most of the changes detected in flood patterns obey natural dynamics, and the response can only be linked to changes in rainfall pattern or sediment availability. (2) There is a relationship between the gravel mining in the Nogalte stream in the last 30 years and physical changes in channel and flood dynamics. (3) Channel changes are the result of ground subsidence resulting from aquifer overexploitation.

\section{Methodology}

To characterize the behavioural changes and geomorphic impact of flooding in the Nogalte area, a detailed field analysis including channel measurements (as topographic cross section survey using a laser distance meter, GPS instrument for positioning and a measuring tape to obtain bank entrenchment), flood stage indicators, sedimentary sections and the resulting morphologic features was combined with geomorphological interpretation of aerial photos, a lidar-derived DEM (digital elevation model) and ground deformation measured by interferometric synthetic aperture radar (InSAR).

We reviewed the information available on the 1973 flood from field data, historical photographs and eyewitness reports, and analysed the field area affected by the 2012 flood, gathering information on water levels at the distal fan and the effects of flooding to compare it with the 1973 event in relation to erosive features and sedimentary forms and grain size. Stratigraphic sections were interpreted at sites where records of both events were preserved. We made measurements of the banks by positioning GPS instruments along the whole length of the main channel of the Nogalte rambla from the apex to the fan area where the channels become blurred.

To identify changes in the Nogalte channel and neighbouring streams through the Upper Guadalentin Depression, we analysed geomorphological parameters including channel width, longitudinal stream profiles and the location and extension of gravel mining, using a combination of aerial images from 1956, 1981, 2004, 2007, 2009 and 2011 provided by Cartomur (www.iderm.es), and $4 \mathrm{~m}$ resolution lidarderived DEMs (LIDARMUR: IDERM, http://iderm.imida. es/iderm/index.htm).

Radar interferometry (InSAR) was used to measure ground motion in the Guadalentín Basin during the period 2003-2010. 27 ENVISAT ASAR (5.6 cm wavelength) images acquired from ascending track 373 were processed using a small baseline approach (Berardino et al., 2002; Hooper, 2008). First, the 27 SAR images were focused and cropped using ROI_PAC (http://roipac.org/cgi-bin/moin.cgi) 
and then 74 interferograms were computed using DORIS software (http://doris.tudelft.nl/) to analyse a $\sim 30 \times 45 \mathrm{~km}^{2}$ area. The topographic phase contribution was removed using a $90 \mathrm{~m}$ digital elevation model from the Shuttle Radar Topography Mission (SRTM) (Farr and Kobrick, 2000). The orbital information used in the processing was provided by the European Space Agency (DORIS orbits).

StaMPS/MTI software (http://homepages.see.leeds.ac.uk/ earahoo/stamps/index.html) was then used to perform pixel selection and interferogram unwrapping. This analysis led to a total of 42842 pixels selected in the study area. A ground subsidence map and profiles were drawn up and compared to the drainage network and flooding distribution.

\section{Geological setting and geomorphology of the Nogalte area}

The case study area is located in the Upper Guadalentín Depression (Murcia, SE Spain) in the internal zones of the Betic Cordillera (Fig. 1). The depression is a Quaternary sedimentary basin developed along the Eastern Betic Shear Zone (EBSZ: Larouzière et al., 1988; Silva et al., 1993a) bounded by mountain fronts controlled by the activity of the Alhama de Murcia fault. The oblique (reverse-strike slip) movement of this fault induced tectonic inversion of the landscape during the Pliocene and Quaternary associated with active uplift. The sinking of the footwall produced the infill with continental deposits overlying Miocene marl and metamorphic rocks from the Alpujárride units (phyllites, quartzites and dolomites).

Pleistocene and Holocene sedimentation consists of alluvial fan deposits, predominantly composed of conglomerates, sands and silts up to $200 \mathrm{~m}$ thick. The distal fan deposits merge to palustrine and playa-lake environments, defining a narrow northeastern-southwestern endorheic zone infilled with silts and clays (Silva et al., 2008).

The current morphology in the depression is defined by the large Nogalte and Lorca alluvial fans. The Nogalte fan consists of coarse material and shows large distal growth incising previous fan deposits. The Lorca fan was fed by overflooding of the Guadalentin River producing mainly clay deposition. The lateral coalescence of the Lorca and Nogalte fans determines a low elevation area occupied by the Béjar Rambla fan, which currently displays high activity in spite of its smaller drainage basin. The low gradient of the distal fans favours the development of a palustrine area that hinders its drainage. This Upper Guadalentín Depression remained endorheic until an artificial channel was built connecting the Nogalte area to the Guadalentin-Segura drainage system. This channel acted as a diversion for floodwaters, but in spite of this the Nogalte floods continued to infill the endorheic area, and only a few flood events reached the Viznaga channel.
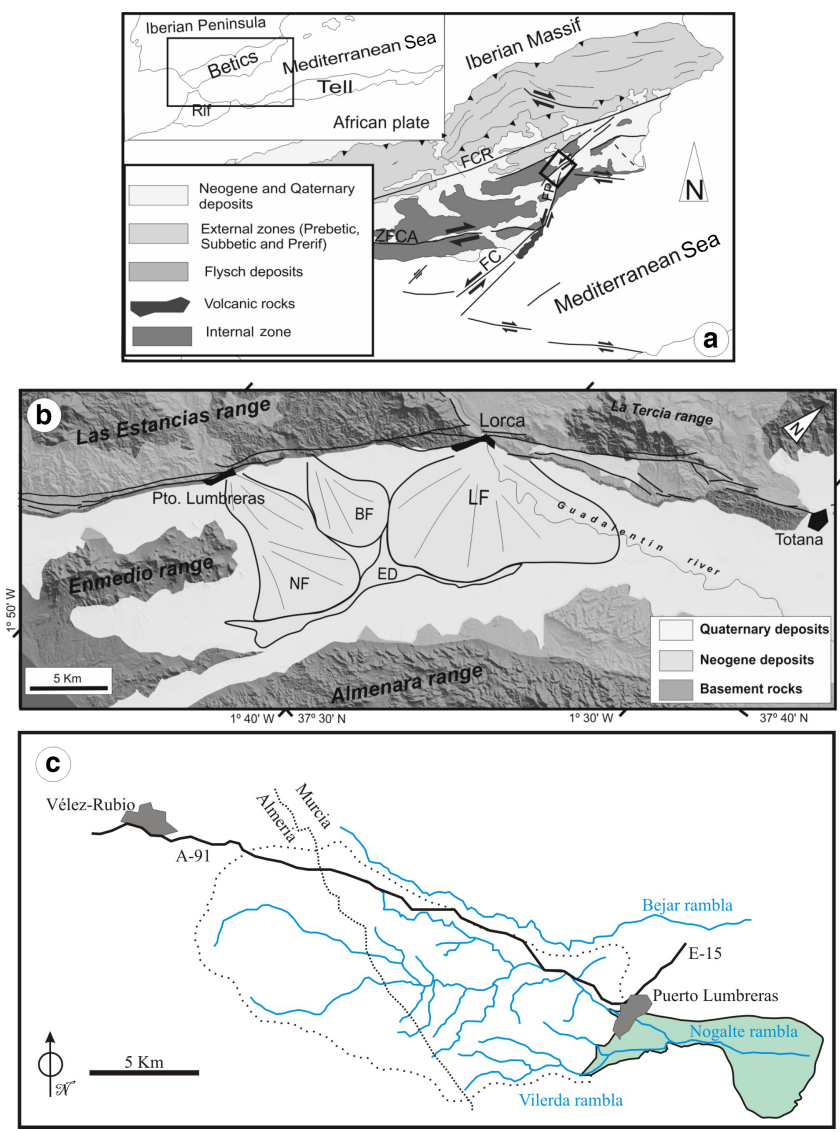

Figure 1. (a) Geological setting of the study area. The black square shows the location of the Guadalentín valley into the Eastern Betic Cordillera. (b) Schematic geological map showing the western part of the Guadalentín Upper Depression and the three main alluvial fans, LF: Lorca fan, BF: Béjar fan and NF: Nogalte fan. ED: endorheic deposits (lacustrine and fluvio-palustrine environment). (c) Nogalte upper and lower basin with the final fan (blue area).

The Nogalte drainage basin covers an area of $171 \mathrm{~km}^{2}$, terminating in a fan with an area of $32 \mathrm{~km}^{2}$. The upper to medium reach drains though a narrow, entrenched, flatbottomed valley, confined in poorly resistant metamorphic rocks. Vegetal cover is scarce, so the system headwaters are highly erodible. The flow regime is ephemeral, dry during most of the year with intense precipitation episodes, and can be considered as natural as no flood control or large check dams have been built in the basin.

In the upper Nogalte basin the sediment types and grainsizes display considerable fluctuations in longitudinal channel profiles, related to temporal variations in sediment supply from the hillslopes (Michaelides and Singer, 2014). In the fan the sedimentation is very active, displaying a clear example of flow spreading (flood-out) where the stream dominates its central axis, and the water is redistributed radially from the channel banks (Conesa-García and Alvarez, 2003; Ortega et al., 2009). The average width of the upper constrained stream 
valley is $50-160 \mathrm{~m}$ with a mean slope of $0.019 \mathrm{~m} \mathrm{~m}^{-1}$. The width of the main channel in the fan lobe is $60-400 \mathrm{~m}$ with a slope of $0.014 \mathrm{~m} \mathrm{~m}^{-1}$. According to Navarro-Hervás (1985), the low bifurcation index (1.06) and relief index (0.026) facilitate slow initial drainage of the water followed by sudden flash flooding.

To characterize alluvial fan differences the longitudinal profiles of the main streams in the depression were obtained using high-resolution $(0.25 \mathrm{~m}$ vertical resolution) lidar-derived DEMs (Fig. 2) to show these profiles for two stream sets. One is formed by streams draining towards the depression axis from its steeply sloping sides (mean slopes 0.023 and $0.014 \mathrm{~m} \mathrm{~m}^{-1}$ ), while the Guadalentín and Viznaga rivers, representing basin evacuation collectors, show a slope 1 order of magnitude lower $\left(0.005\right.$ and $0.003 \mathrm{~m} \mathrm{~m}^{-1}$ respectively). A significant exception is the Tiata Rambla (Fig. 2), developed on the Lorca fan surface, with a profile displaying an atypical low slope $\left(0.005 \mathrm{~m} \mathrm{~m}^{-1}\right)$. The sediments in this fan consist of the thinner overflow and dispersion deposits from floods triggered by the Guadalentín River, while the other neighbouring streams are dominated by gravel sediments.

\section{Hydrology of the 2012 event. Was the flood behaviour comparable to the 1973 event?}

More than 20 large floods have been recorded in this area since 1568 (Gómez-Espín, 2004; Ortega, 2007). However, the 1973 event is considered the most catastrophic (Heras, 1973; López-Bermúdez and Gutierrez, 1983, among others). A mesoscale convective system (MCS) affecting the whole of southeast Spain was the origin of intense, persistent rainfall on 3 consecutive days (Capel Molina, 1974). Antecedent rainfall was a significant factor, with $200 \mathrm{~mm}$ recorded in the 3 days before the event. Intense precipitation (although under $100 \mathrm{~mm}$ day $^{-1}$ and with a 50 -year return period) led to a peak discharge with an estimated range of $1974-2100 \mathrm{~m}^{3} \mathrm{~s}^{-1}$ (Table 1). Spatial distribution of rainfall in 1973 was nearly homogeneous, with $151 \mathrm{~mm} / 24 \mathrm{~h}$ and $215 \mathrm{~mm} / 48 \mathrm{~h}$ in Velez Rubio, located in the Nogalte upper basin. In the lower basin (Puerto Lumbreras), the daily record was $96 \mathrm{~mm} / 24 \mathrm{~h}$ and $160 \mathrm{~mm} / 48 \mathrm{~h}$ (Fig. 1c). Radar data that provide a spatially detailed representation of the rainstorms were not available during the 1973 event. Significantly, Heras (1973) claimed that the estimated solid discharge was ca. $813 \mathrm{~m}^{3} \mathrm{~s}^{-1}$, or $40 \%$ of total discharge, producing a large logjam at the $100 \mathrm{~m}$ long village bridge and justifying the severity of the damage caused.

The 28 October 2012 flood event studied here was provoked by a convective rainfall episode driven by an isolated upper-level low (IDHL), with $180 \mathrm{~mm}$ of rainfall in $24 \mathrm{~h}$, $25 \%$ of the total in $1 \mathrm{~h}$ and an intensity of $119.6 \mathrm{~mm} \mathrm{~h}^{-1}$ (Gil Meseguer et al., 2012). In a previous study, some of the present authors (Ortega et al., 2009) estimated the precipita-
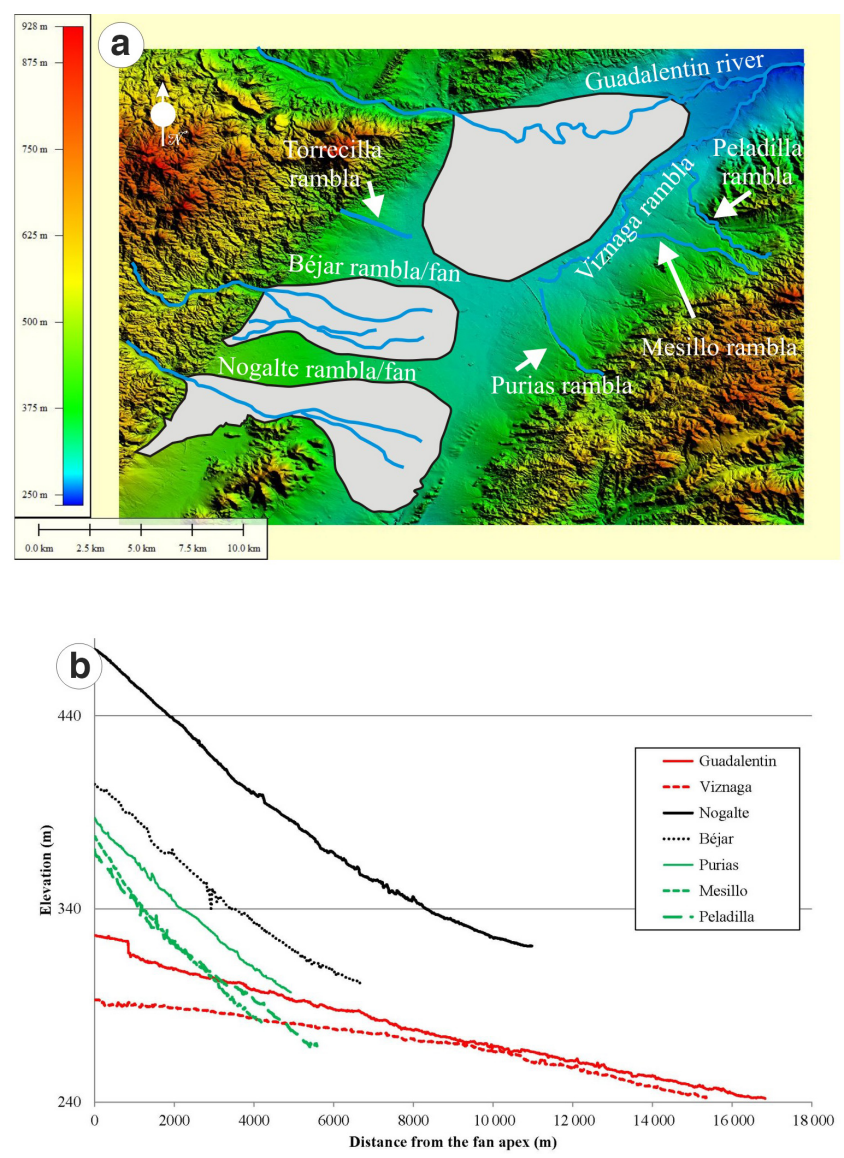

Figure 2. (a) Location of the main streams in the Guadalentín Upper Depression. (b) Longitudinal profiles of the main streams. Black lines: tributaries of the left margin. In green: tributaries of the right margin. In red: streams in the Guadalentín valley axis.

tion in Puerto Lumbreras to be $190 \mathrm{~mm} \mathrm{day}^{-1}$ for a 500 -year return period. Therefore, the rainfall in the 1973 event was lower than estimated for this period, but the 2012 event may be assigned to a 500-year return period.

The resulting peak discharge recorded in 2012 was somewhere between 1500 and $2489 \mathrm{~m}^{3} \mathrm{~s}^{-1}$ depending on the author (Table 1). This may be considered as a high magnitude event compared with the 500-year return period proposed by Conesa-García (1995) for a discharge estimated as 1859 and $1900 \mathrm{~m}^{3} \mathrm{~s}^{-1}$ (Pernia et al., 1987). Benito et al. (2012), however, consider it a moderate to high flood, slightly less than in 1973.

The comparison of the 1973 and 2012 flood events, which most authors classify as exceptional, shows the different rainfall mechanisms (MCS vs. IDHL) and amounts of water precipitated before the flooding event (Fig. 3). Although a similar peak discharge is given for both floods, both showing around $2000 \mathrm{~m}^{3} \mathrm{~s}^{-1}$ in the cumulative hydrograph, the persistence of a high discharge over time was different.

In the 1973 event, the high entrainment capability of previously wetted soils in the watershed could explain the high 
Table 1. Estimated peak discharge and rainfall during the 1973 and 2012 events in the Nogalte channel. Data taken from several sources.

\begin{tabular}{lrr|rr}
\hline Author/s & \multicolumn{2}{c}{1973 event } & \multicolumn{2}{c}{2012 event } \\
& Rainfall $(\mathrm{mm} / 24 \mathrm{~h})$ & Discharge $\left(\mathrm{m}^{3} \mathrm{~s}^{-1}\right)$ & Rainfall $(\mathrm{mm} / 24 \mathrm{~h})$ & Discharge $\left(\mathrm{m}^{3} \mathrm{~s}^{-1}\right)$ \\
\hline Heras (1973) & & 2100 & - \\
Capel Molina (1974) & 96 & - & - \\
López-Bermúdez and Gutierrez (1983) & - & 2000 & - & - \\
Gómez-Espin (2004) & 100 & 1974 & - & - \\
Benito et al. (2012) & - & 2000 & - & 1800 \\
Gil Messeguer et al. (2012) & - & - & 162 & 2356 \\
CHS (2014) & - & - & 2489 \\
\hline
\end{tabular}

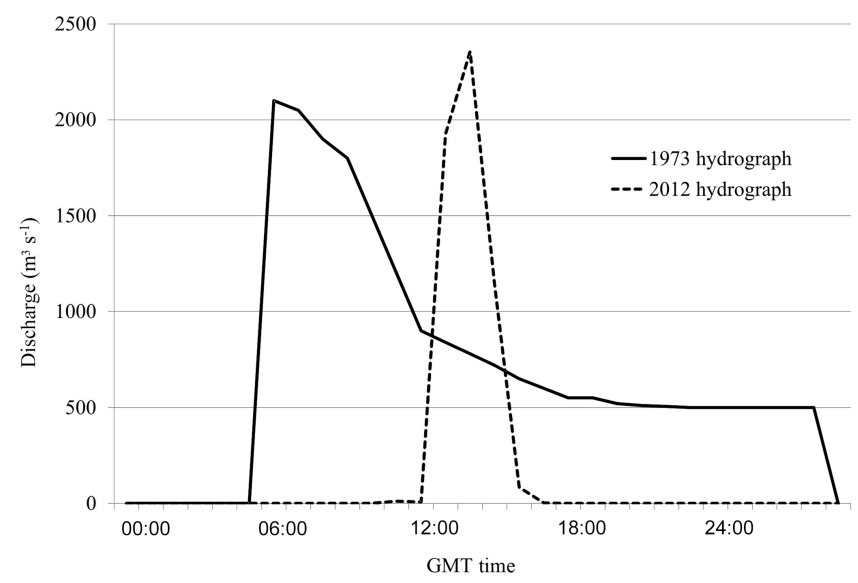

Figure 3. Peak discharge recorded by the SAIH hydrologic warning system for the Nogalte Rambla in Puerto Lumbreras during the 28 September 2012 flood and comparison with the hydrograph of 1973 event.

amount of solid discharge transported. The load value of ca. $40 \%$ referred by Heras (1973) may be too high, considering that based on the boulder size he reported $(0.60-$ $1.60 \mathrm{~m}$ diameter) that the Manning coefficient would have to be around twice the 0.049 value he used. The solid discharge would therefore be less than $40 \%$, although high enough in each case to be a relevant issue to establish differences between the flood results.

Both hydrographs (Fig. 3) indeed, despite showing similar peak discharge, show differences in cumulative water and persistence in time, with worse effects in the 1973 event than in the 2012 flood event, at least in theory. A different spatial distribution of rainfall could be also considered, but as discussed, all stream headwaters were homogeneously affected during both floods. Nevertheless, although the differences in antecedent rainfall may have been of great significance, we do not consider this to be enough in itself to explain all the differences observed in the hydromorphological dynamics of this most recent flash flood. As already observed, in the 1973 flood the major changes were located in the upper catchment and fan apex due to the high bedload transported, but the effects of the 2012 flood event were concentrated in the medium to lower fan reaches.

\section{Gravel mining effects in hydromorphological flood dynamic}

One of the most significant recent human-induced changes in the Nogalte Rambla is the extraction of gravel for construction. The Nogalte active channel has been intensively exploited for gravel mining by both digging and machine headcutting since 1981, as can be observed in aerial photos, especially from 2002 onwards. According to our measurements using a DEM derived from lidar data from Cartomur-IDERM (2016), with a $4 \mathrm{~m}$ horizontal resolution and a vertical accuracy of $<50 \mathrm{~cm}$, the gravel pits exploited in the stream bed affected around $30 \%$ of the channel during the period 19562009 (Fig. 4b and c), starting gravel pit mining in 1981. The width of the Nogalte channel has changed between the first aerial photos taken in 1956, where no gravel pits are shown, and the most recent photos from 2009. There is a significant reduction in the area occupied by the channel in map views (Fig. 4c) between $1956\left(\sim 23 \mathrm{~km}^{2}\right)$ and $2009\left(\sim 19 \mathrm{~km}^{2}\right)$. It can be seen that the channel tends to narrow along the whole length of the stream, but this is especially notable in relation to the active mining in each section. Values for these changes reach $39 \%$ in the sections where gravel extraction is the greatest and $-7 \%$ in sections with less impact (Fig. 4d).

The field data obtained from the channel depth after the 2012 flood together with the high-resolution DEM measurements allowed us to quantify recent Nogalte channel entrenchment. The results of the field analysis (Fig. 5) indicate a variable channel incision rate in the fan apex reach. Entrenchment values in the Nogalte fan are very irregular in the first few kilometres of the stream course due to local gravel removal. Bank undermining appears to be closely related to recent gravel pits, where down-cutting can reach values of up to $6 \mathrm{~m}$.

Mean entrenchment values throughout this upper fan section are around $2.2 \mathrm{~m}$. Temporal variations in the longitudinal profile and channel slope could not be measured due to a lack of information prior to the 2012 flooding event. 


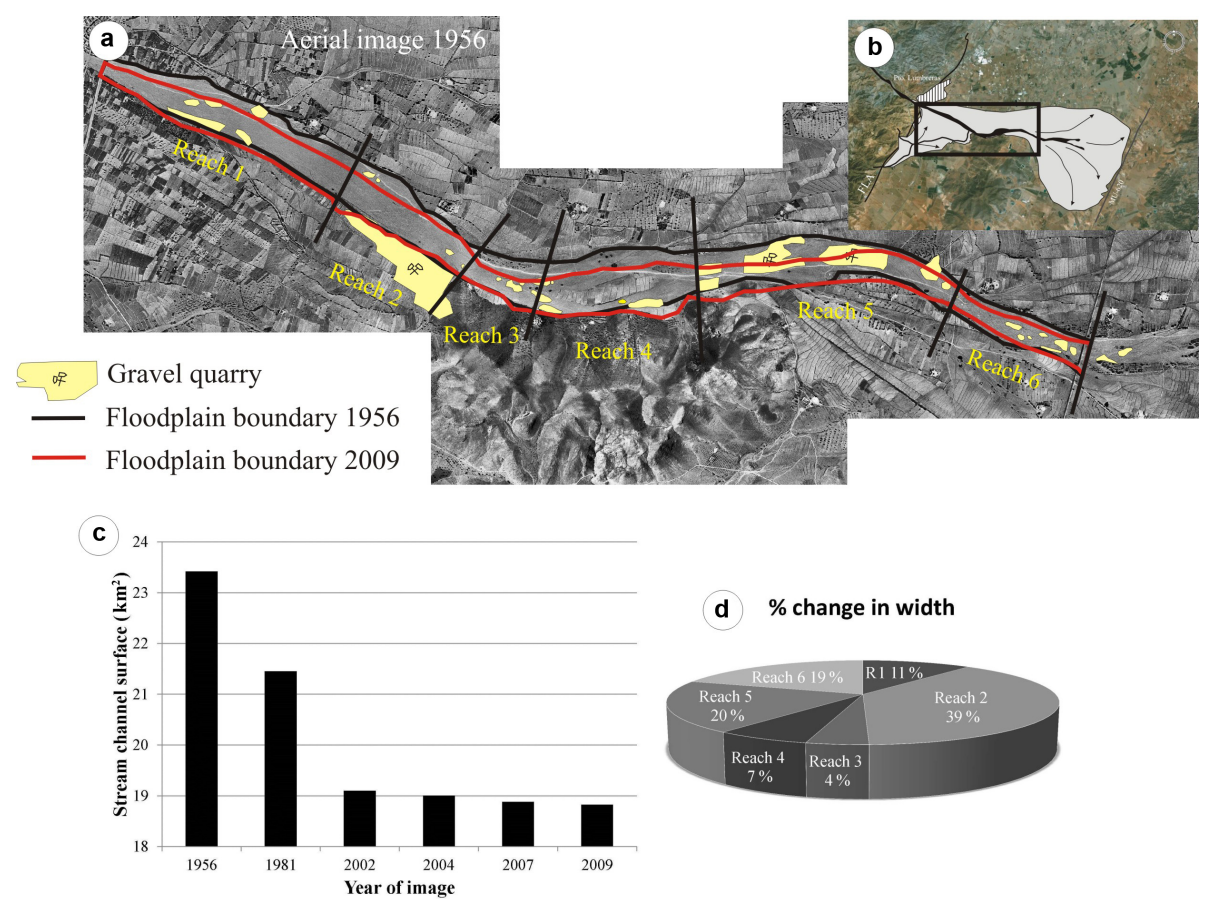

Figure 4. (a-b) Location of the studied channel reaches and entrenchments showing channel bank boundaries change between 1956 and 2009 and related gravel quarries. (c) Recent evolution in stream channel area. (d) Percentage of channel width change for each reach.

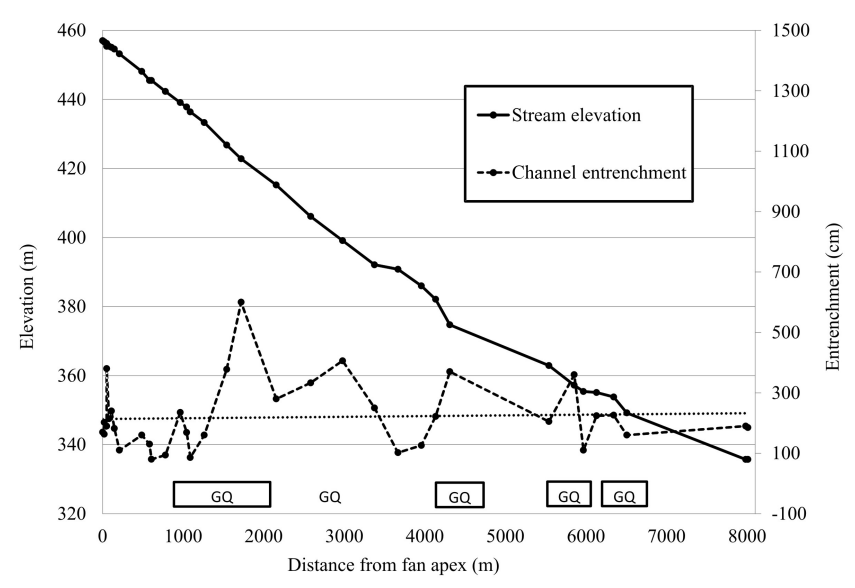

Figure 5. Nogalte River longitudinal profile and its channel banks entrenchment and related presence of gravel quarries (GQ).

Our field results show that the longitudinal stream profile (Fig. 5) is rapidly homogenized and flattened by river dynamics, which coincides with the results of the research conducted by Singer and Michaelides (2014) in the confined Nogalte valley reach.

We also compared mean entrenchment in the Nogalte Rambla with incision values obtained for other nearby streams using a high-resolution DEM derived from lidar data. In the Nogalte Rambla reaches where the values are not affected by recent gravel pits, detected incision is much lower at around $1.7 \mathrm{~m}$. If the sections with gravel pits are also considered, mean entrenchment values of up to $2.2 \mathrm{~m}$ are obtained. In the neighbouring streams, mostly unaffected by mining, the entrenchment values are lower, but still significant: Béjar: $0.91 \mathrm{~m}$, Viznaga: 1.56 and Guadalentin: $1.6 \mathrm{~m}$.

These results show that the whole fluvial network is undergoing significant entrenchment. This is an important factor to explain the significant distal effects and extent of the 2012 flash flood event, and allows aspects of the flow dynamics to be reconstructed and explained, taking recent anthropogenic interference into account.

The section of the Nogalte Rambla flowing through the village of Puerto Lumbreras is artificially channelled and the induced increase in water velocity hindered deposition, favouring greater incision and bank erosion immediately downstream at the fan apex (Fig. 6a). Sedimentary sections surveyed (Fig. 7) show ca. 2-3 m thickness for the 1973 deposits with boulders, while the 2012 sediments consist of only $20 \mathrm{~cm}$ on top of the previous flood deposits.

A couple of kilometres further downstream, a gravel quarry (area $137138 \mathrm{~m}^{2}$, depth $4 \mathrm{~m}$ and estimated total volume of gravel extraction $5.4 \times 105 \mathrm{~m}^{3}$ ) acted as a major interference in the channel, inducing significant backward erosion with intense upstream undermining and widespread pit remodelling (Figs. $6 \mathrm{~b}$ and $4 \mathrm{~b}$, reach 2 ). The partial bedload retention in the mining hollow involved sediment deficit downstream compensated by new material eroded from the stream banks. Reaches with channel widening and lateral flow ex- 

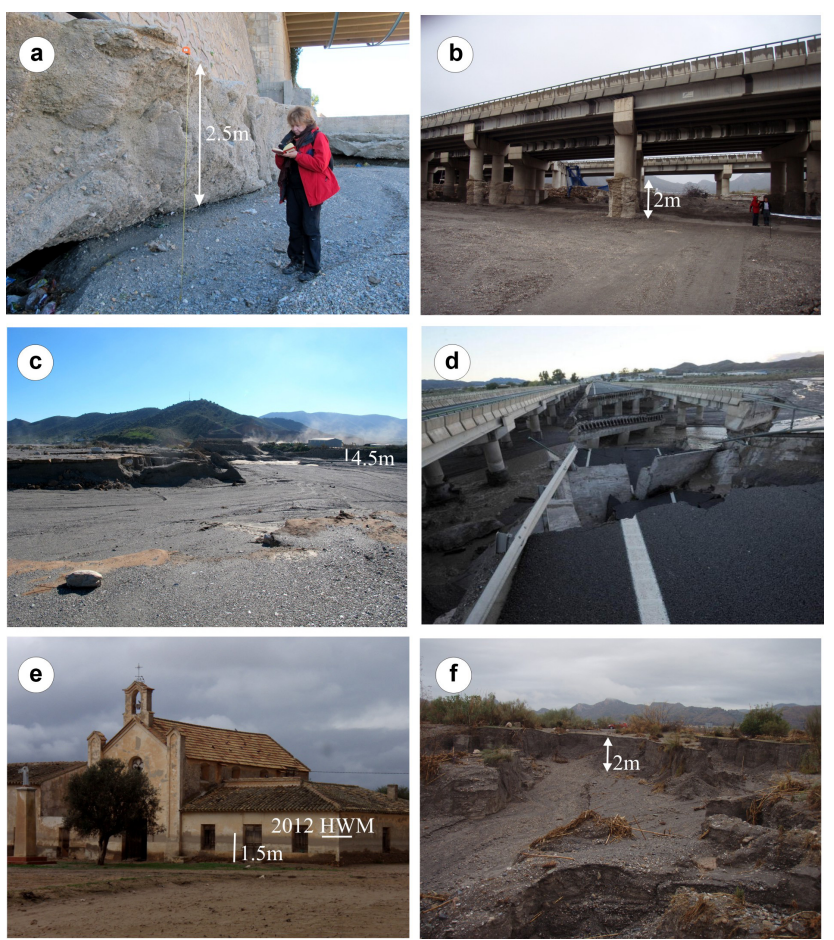

Figure 6. Pictures from the 2012 flood effects. (a) Entrenchment of $2.5 \mathrm{~m}$ below Puerto Lumbreras Bridge. (b) In-channel gravel quarry in Nogalte fan apex showing $4.5 \mathrm{~m}$ channel entrenchment. (c) Escucha Chapel in Nogalte distal fan area showing the $1.5 \mathrm{~m}$ high water mark from 2012 event. (d) and (e) Gravel mining impact on A-7 highway bridge after 2012 event; pillars are exposed in $2 \mathrm{~m}$. (f) Headwards erosion due to gravel mining in the Béjar Rambla.
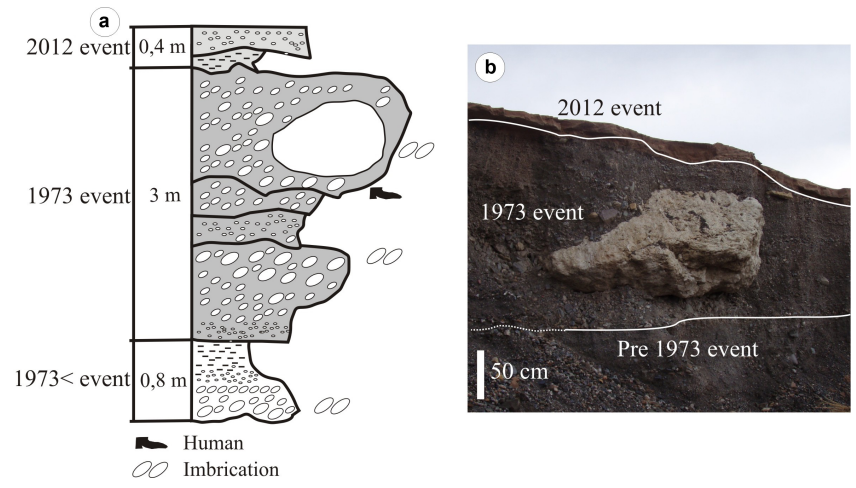

Figure 7. Sedimentary section from 2012, 1973 and older floods recorded in the banks of Nogalte Rambla at Puerto Lumbreras.

pansion have been established, alternating with newly entrenched reaches, causing the collapse of a railway bridge further downstream.

Channel incision decreased towards the distal part of the fan and the channel was widened with lateral flow and the formation of thin but extensive sandy bars and silt deposits. However, the flow was still concentrated and had high depth and velocity values (Fig. 6c) when it reached the flat en-

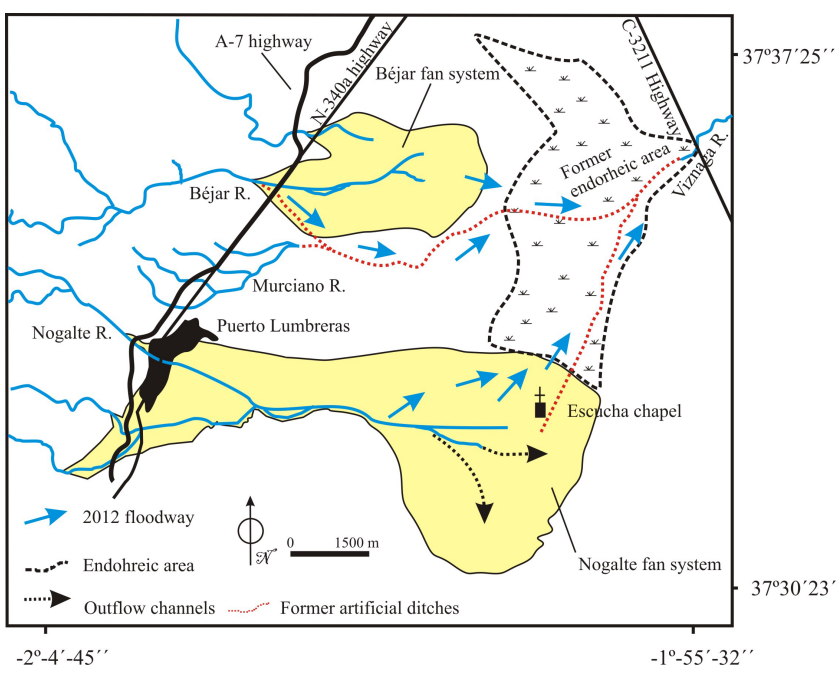

Figure 8. Evolution of the 2012 flood from the medium Nogalte fan and the Béjar stream (blue arrows) following former artificial ditches through Viznaga Rambla, flooding endorheic areas at the end of the Nogalte distal fan (Escucha Chapel) and confined areas around the $\mathrm{C}-3211$ highway.

dorheic playa, favouring flow continuity towards the northern depression outlet (Fig. 8).

In this context, the formerly endorheic area displays a change in flood dynamics with major erosive effects upstream reshaping an entrenched channel in the apical fan reach, followed by an increase in water velocity and flow depth in the distal fan lobes. During the 1973 flood event the Escucha Chapel, located in this lower area (Fig. 8), was only affected by stagnating floodwaters with low water velocity and fine-grained deposition. In contrast, the 2012 floodwaters reached this area with high flow depth values $(>1.5 \mathrm{~m}$. see Fig. 6c), and the water velocity may have reached $1 \mathrm{~m} \mathrm{~s}^{-1}$, as suggested by the resulting scours and bars compared with similar features studied in other flood events (Ortega et al., 2014). In this case, instead of the flow stagnating, the floodwaters continued downstream, unable to retain such a high flood volume on the broad, flat endorheic area (Fig. 8). A new floodway developed, reshaping a wide flood corridor connected to the Viznaga diversion channel, as the artificial outlet of the endorheic depression was no longer functional.

Also significant for the flooding extension in this area was the confluence with water arriving from the Béjar fan system (Fig. 8), which was also seriously affected by rainfall. Recently built industrial estates limited infiltration, concentrating flows, and this together with extensive gravel extractions favoured undermining along the rambla channel and even led to the collapse of the A-7 highway bridge (Fig. 6d, e and f). Several braided streams converged here and joined the water from the Nogalte Rambla, extending over both distal areas towards the common outflow (Fig. 8). The resulting flow, 
already channelled, continued north and finally encountered the artificial Viznaga Rambla.

From the flood description we can deduce the relative importance of human activities such as gravel mining in exacerbating flow concentration instead of dispersing the water along the fan. The 1973 flood event produced rapid deposition as soon as the floodwater spread out, depositing its large load with the decreasing gradient on entering the Upper Guadalentín Depression. The large sediment load was therefore significant in the upper basin and fan apex. Thus the role of the solid discharge may have been determinant in the behaviour of each flood, both because the 2012 flood did not transport a large sediment amount from the upper catchment, and also because the gravel pits induced load deficit in the channels along the fan.

\section{Changes in drainage system induced by groundwater overexploitation}

A third factor that needs to be taken into account is the InSAR-detected ground subsidence due to groundwater overexploitation and how this may affect the observed change in flooding pattern.

To analyse the InSAR-detected ground deformation with this lower water level we developed an average velocity map for ground deformation rates using InSAR analysis for the period 2003-2010 (Fig. 9a). The measurements are in the satellite's line of sight (LOS) with an angle of $23^{\circ}$ from the vertical, and thus they are mostly sensitive to vertical displacements. The deformation pattern is elongated in a $\sim \mathrm{N} 45^{\circ}$ E direction, parallel to the Upper Guadalentín Basin. Maximum deformation rates of $\sim 10 \mathrm{~cm} \mathrm{yr}^{-1}$ are located at the centre of the basin (red dots), in agreement with previous results (González and Fernández, 2011; Rigo et al., 2013). Deformation ends at the south between the Béjar and Nogalte channels, but continues towards the northeast following the Guadalentín River, outside the case study area.

To compare the measured ground deformation with the flooding pattern detected during the 2012 event, we projected the deformation along the four main channels in the region: the Guadalentín River and the Viznaga, Béjar and Nogalte streams (Fig. 9b, profiles A to H). These cross sections and longitudinal profiles along the main rivers show that the largest area of sinking occurs along the Guadalentín River with deformation rate values between 2.5 and $10 \times 10 \mathrm{~cm} \mathrm{yr}^{-1}$, together with the Béjar Rambla channel, with a maximum deformation rate of $\sim 7 \times 10 \mathrm{~cm} \mathrm{yr}^{-1}$, increasing towards the centre of the basin. The Nogalte channel does not show any deformation pattern, suggesting either the absence of deformation along this channel or deformation below the stability threshold of the InSAR measurements $\left(\sim 1 \mathrm{~cm} \mathrm{yr}^{-1}\right)$. The Viznaga channel surrounds the area of the valley affected by more rapid subsidence, but in this case the velocity profile shows that the sinking may be less than $1 \mathrm{~cm} \mathrm{yr}^{-1}$.

The areas depicted with different subsidence rates show a roughly similar morphology to that of the alluvial fans (Fig. 10). The maximum subsidence area corresponds to the Lorca fan, with values of $7-10 \mathrm{~cm} \mathrm{yr}^{-1}$; the smaller area corresponding to the Béjar Rambla presents lower values (4$7 \mathrm{~cm} \mathrm{yr}^{-1}$ ); and the Nogalte fan shows no subsidence.

In order to understand the significance of this subsidence we analysed the recent evolution of the hydrogeological configuration. The Upper Guadalentín Depression unconfined aquifer developed in the highly permeable conglomerates and sands of the Plio-Quaternary alluvial fan deposits. Given the growth of intensive agriculture, the aquifer began to show evident signs of overexploitation in 1972, and was officially declared overexploited in 1987 . Water withdrawal $\left(43.3 \mathrm{~h} \mathrm{~m}^{3}\right.$ year $\left.^{-1}\right)$ was 4 times higher than natural input $\left(11.5 \mathrm{~h} \mathrm{~m}^{3}\right.$ year $\left.^{-1}\right)$, which has resulted in a drop of up to $200 \mathrm{~m}$ in groundwater piezometric surface (IGME, 2009).

Earlier hydrogeological maps showed a northeast underground flow, with a $0.85 \%$ gradient, fed by the lateral alluvial fans (IGME, 1975). In contrast, the 1993 map shows that overexploitation had led to a $150 \mathrm{~m}$ water table drop (IGME, 2009), with the resulting endorheic aquifer flowing towards the depression centre (Fig. 11a). The lowering of the water table intensified in 2008, and the underground flow inverted southwards (Fig. 11b), a trend that continued in 2012 (Fig. 11c) according to the latest data published (CHS, 2014).

These results indicate that the current state of the aquifer described (Fig. 11c) does not show any apparent relationship with the ground deformation map derived from InSAR analysis (Figs. 9 and 10) for the 2003-2010 period. However, this deduced ground deformation appears to be reflected better in the 1993 groundwater contour map. As shown in Fig. 11a, the highest groundwater flow gradient corresponds to the Lorca fan, the lowest gradient coincides with the Nogalte fan and the Béjar fan presents an intermediate value.

This configuration can be inferred if we consider a delay occurring between the groundwater table drop and its effect on surface subsidence. A time delay could explain the current absence of subsidence in the Nogalte fan area, since the piezometric drop there only recently became evident during the period 2008 to 2012 (Fig. 11b and c). Other InSAR studies of aquifer-related subsidence in the Guadalentín Depression also suggest non-linear time-delayed flow processes (González and Fernández, 2011), and more recently Boni et al. (2016) conclude a similar delay.

Lithology is another important parameter to consider when interpreting differences observed in ground subsidence analysis. The dissimilar behaviour of the Lorca and Nogalte fans may derive from their geological characteristics. As described in the longitudinal stream profiles (see Fig. 2b) there is a significant difference in fan slope due to lithology. The Lorca fan is fed by the Guadalentín River, whose welldefined floodplain favoured clay sedimentation. The greater 


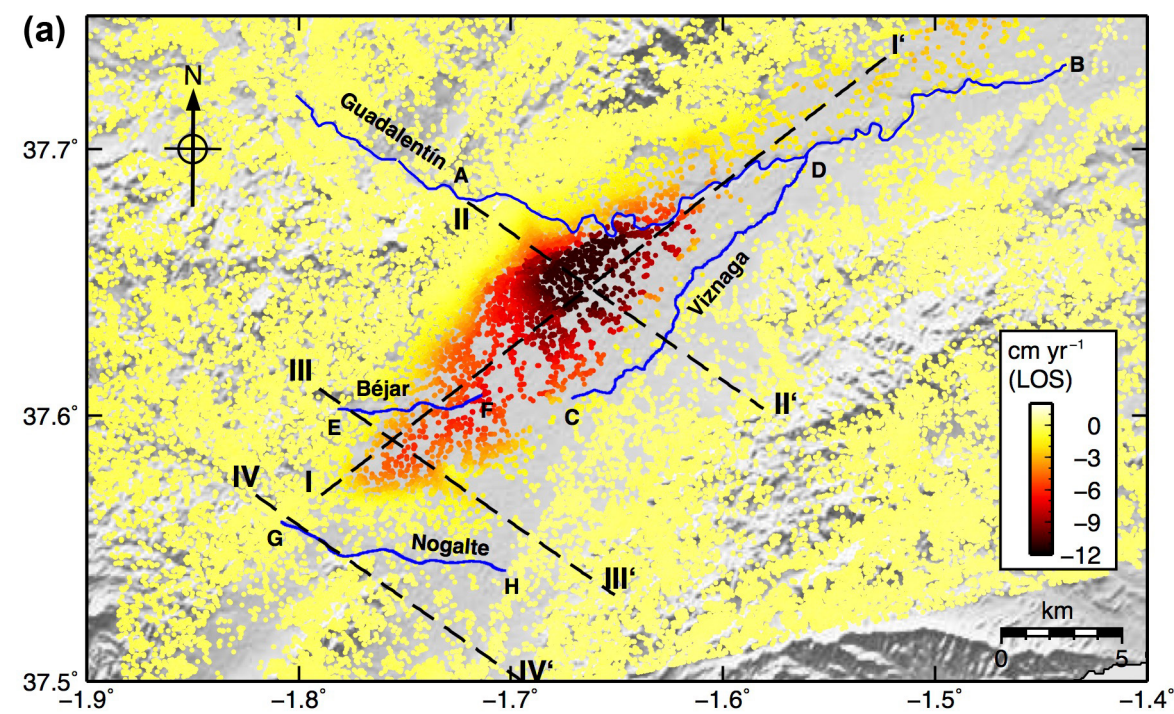

(b)
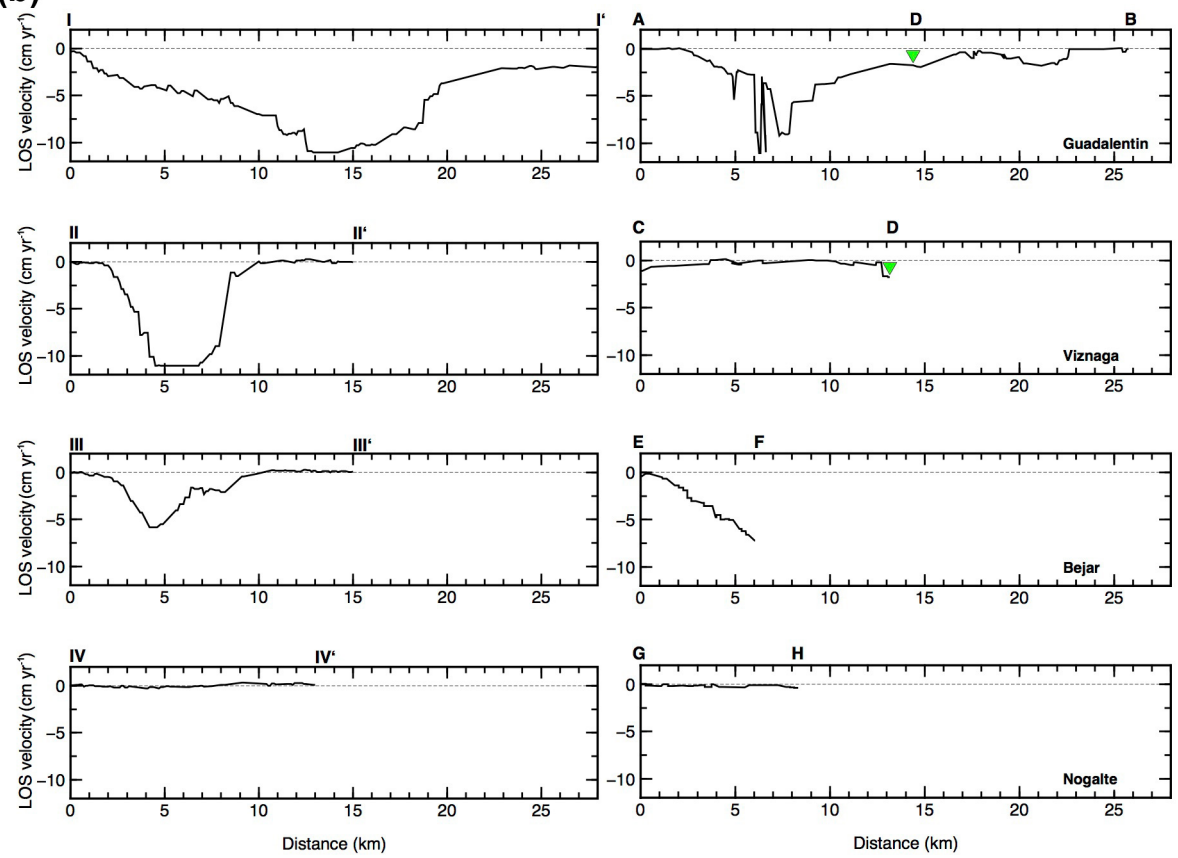

Figure 9. (a) Ground deformation measured by InSAR: coloured dots represent InSAR velocities for the period 2003-2010 in the satellite's line of sight (LOS, $\sim 23^{\circ}$ from the vertical). The four channels analysed in this work are represented by black lines. (b) Cross sections: ground deformation velocities measured along the four discontinuous white lines in A (profiles with flags I-IV) and along the four channels identified in the map (profiles with flags A-H).

compressibility of these deposits may explain the higher subsidence rate than that found in the Nogalte fan, which is composed of coarse sediments. Delayed compaction during land subsidence was also explained by González and Fernández (2011) due to the presence of low permeability materials.

An additional factor justifying the larger subsidence rate in the Lorca fan is its current disconnection from its feeding stream, the Guadalentín River. The channelization of this stream diverting it from the Lorca fan apex not only avoids overbank flooding towards the fan but also prevents the underground connectivity responsible for its groundwater recharge. Moreover, a large dam upstream has drastically reduced the flow through the Guadalentín River.

The important accumulation of the 2012 floodwaters in the distal fan endorheic area may have acted as a driving factor for subsidence manifestation. Floods often trigger change in metastable-state systems (Schumm, 1973), which means an external factor favours overcoming a threshold and deter- 


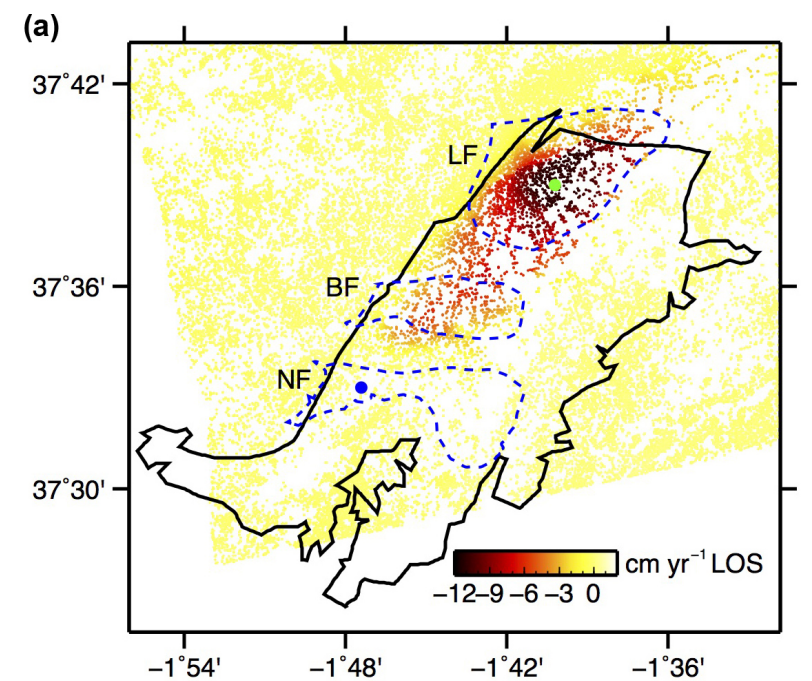

(b)

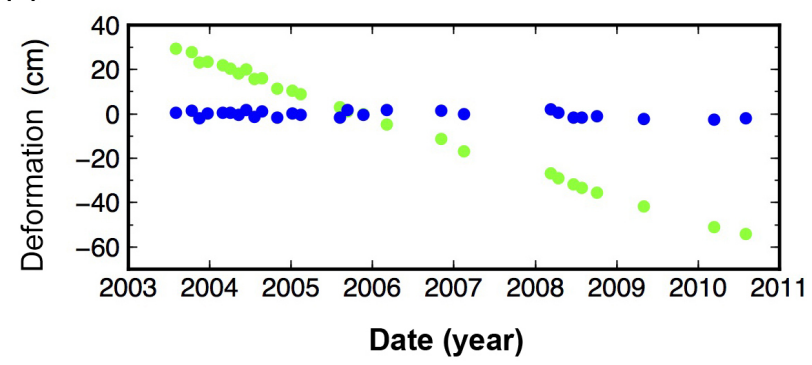

Figure 10. (a) Map showing ground deformation over the Alto Guadalentín aquifer (delineated by the solid black line). The dashed blue lines indicate the location of the three fans shown in Fig. 1b (LF: Lorca fan, BF: Béjar fan and NF: Nogalte fan). (b) Temporal evolution of deformation for two locations in the study region. Green points represent deformation for the location of the green point in (a), and blue points represent deformation for the location of the blue point in (a).

mines a new equilibrium regime. Distal endorheic areas are composed of silts and clays with interbedded sand and gypsum deposits. These characteristics favour collapsible soils that are metastable under dry conditions, but lose strength when wet.

The appearance after the flood of a large crack in the soil (Fig. 12), hundreds of metres long and several metres wide and deep, may evidence ground settlement. The crack developed in the lower reach of the Béjar Rambla where coarse deposits transition to distal clays. In fact, the local name for this site ("Bujeos" or holes) is coherent with the occurrence of especially compressible clays in this area. More detailed studies are needed to test the response of these materials and their potential role in the subsidence delay process detected.

\section{Discussion}

In addition to the characteristics of the rainfall event itself, two other significant causes must be taken into account to understand the changes in the unusual hydromorphological dynamics of the 2012 flash flood studied here: human activities such as in-channel gravel mining and severe ground subsidence due to groundwater withdrawal. Both of these involve channel stability control factors: the first leads to a deficit of load material in the drainage system, and the second to the loss of substrate support resulting in base level lowering. They may justify the geomorphological changes observed, i.e. the tendency to stream entrenchment and the unexpected extent of the flood.

Although the September 2012 total flood volume was only medium-high, the rainwaters were concentrated into a $2 \mathrm{~h}$ period. Hydraulic variables do not explain channel response to floods sufficiently (Surian et al., 2016), and other factors such as sediment supply are necessary to understand major geomorphic changes. In Mediterranean regions, flash floods mainly occur in autumn under low soil wetness conditions (Marchi et al., 2010). Sudden, highly intensive rainfall with no antecedent precipitation is a determining factor hindering sediment entrainment from the catchment, as this requires existing available material previously prepared by wetting and disaggregation. Flood duration is a decisive factor in erosion. Costa and O'Connor (1995) suggested that the long duration of flood flows together with stream power explain the driving forces for significant geomorphic changes. Ortega and Garzón (2009) tested the effects of a high magnitude flood in the Rivillas River (southwestern Spain), showing that a long duration peak discharge generated more effective impacts. The comparison between the $2 \mathrm{~h}$ duration of the 2012 flood and the ca. $6 \mathrm{~h}$ peak discharge, plus the antecedent rainfall effect in 1973 (see Fig. 3), should be enough to explain the rapid rainfall concentration and the low entrainment capability of the 2012 event.

The fact that the 2012 rainfall was concentrated into a small time period, and soil moisture was low due to the summer drought, may have led to faster flood propagation downstream. This load deficit could, however, have been quickly corrected downstream from Puerto Lumbreras by renewed channel erosion of the channel banks followed by channel bed accretion, as the response proposed by Schumm (1977) for load deficit adjustment on bedload streams. The brief time span of the precipitation would have displaced the flood slightly downstream, but would not have induced the significant morphodynamic changes described at much greater distances.

The Nogalte Rambla is prone to shifting in sedimentation areas and flood dispersal within its fan, but we found no previous references to deep, high energy flood propagation downstream from the endorheic area. A flood model proposed by Conesa-García and Alvarez (2003) even considered that, due to its more concave profile, the vulnerabil- 

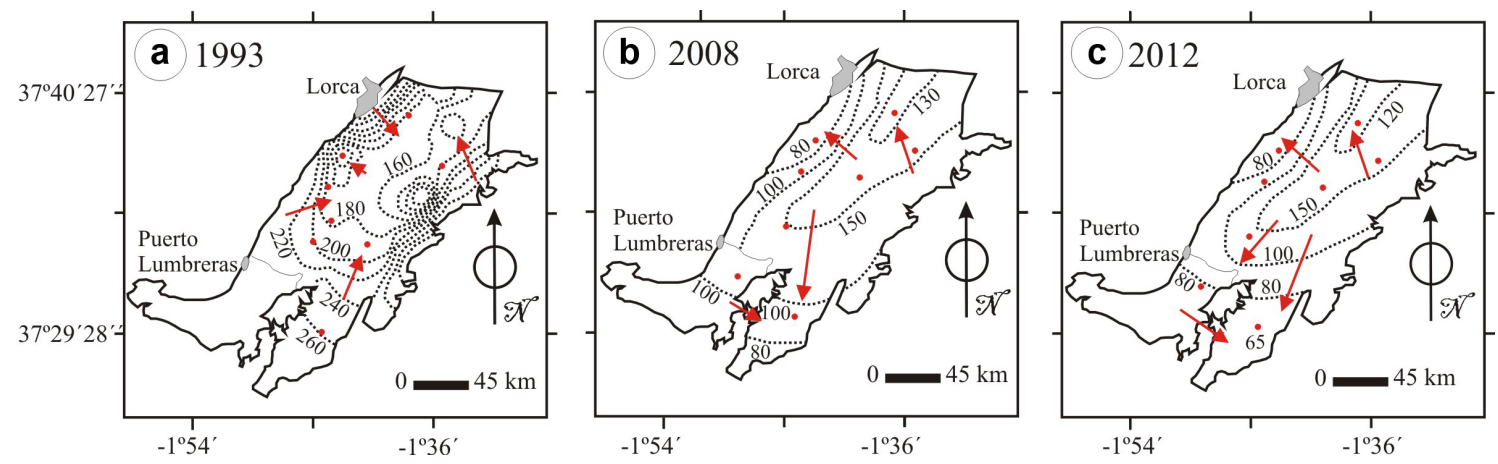

Figure 11. Temporal evolution in the Alto Guadalentín aquifer piezometry. (a) 1993 piezometric contour lines with overexploitation signs. (b) Aquifer in 2008 with inverse groundwater flow. (c) Drop in groundwater surface in 2012 (source: modified from IGME, 2009 and CHS, 2014).
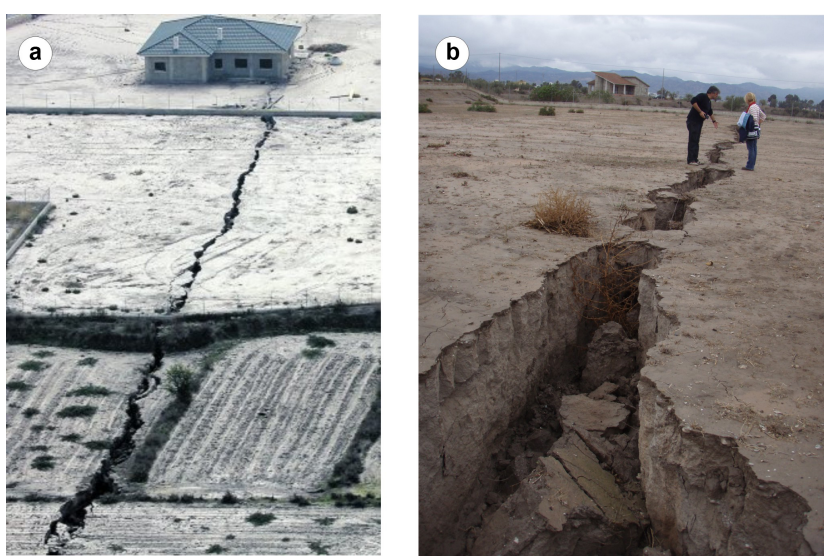

Figure 12. Compaction on clay soils interpreted due to compressibility after groundwater overexploitation. (a) Large crack development on vertisols in the Béjar fan distal area (source: La Verdad de Murcia). (b) Crack detail up to $150 \mathrm{~cm}$ width and $2 \mathrm{~m}$ height.

ity to flooding was greater towards the southern edge of the fan axis. The only reference found to previous flood propagation downstream from the endorheic area is the 1948 flood in which $240 \mathrm{~mm}$ rainfall in only $5 \mathrm{~h}$ was recorded in Puerto Lumbreras, resulting in a flash flood that affected an area of 7900 ha (Perez and Gil, 2012). The flooded area was smaller than the $116 \mathrm{~km}^{2}$ of the 2012 event, and affected mainly the lower part of the depression, as the floodwater arrived mostly from the Lorca fan through La Tiata channel, not from the Nogalte Rambla.

The significance of load discharge for channel incision was pointed out by Segura-Beltrán and Sanchis-Ibor (2013) in a similar Mediterranean ephemeral stream environment. They showed that even when large floods are responsible for transporting high amounts of sediment, channel incision only occurs when there is a supply deficit, similar to what happened in their case study following basin afforestation. As also indicated by Hooke and Mant (2000), large events in this area are responsible for major channel changes, although they frequently only mobilize riverbed material.

A more serious effect on stream pattern may derive from in-channel gravel mining. The consequences of in-channel gravel extraction are well described in the literature, as the gravel pit produces a nick point migrating upstream (e.g. Scott, 1973; Schumm et al., 1984; Kondolf, 1997; Wohl, 2000). Moreover, hungry waters (Kondolf, 1997) prompt the propagation of channel bed and bank erosion downstream to recover the sediment deficit. The river system has negative feedback; any change introduced affects reaches both upstream and downstream (Schumm, 1977). There is inertia between cause and effect, and the higher average shear stress caused by incision can aggravate degradation (Martin-Vide et al., 2010). The result is an adjustment of the stream profile and variations in channel width, depth and slope along the longitudinal profile.

In this present case study, gravel mining may explain the considerable channel entrenchment observed as it concentrates flow and contributes to increased erosion and removal of entrained sediments. These consequences have intensely affected the Nogalte and Béjar ramblas watercourses, and have even caused a bridge collapse in active incising reaches. The loss of material has induced upstream entrenching to fill the hole generated, but the removal of this material from the system will also be reflected downstream. According to Martin-Vide et al. (2010), in semi-arid braided rivers the loss of alluvial material resulting from incision may be as much as twice the volume of gravels mined. As we have observed in this case widespread entrenchment also occurred downstream, although less abruptly than upstream. Channel adjustments are dependent on the reach-scale sediment budget (Wishart et al., 2008) and sediment fluxes display greater discontinuity and complexity in comparison with water discharge (Rice, 1998).

The other important factor conditioning this flash flood results is the subsidence caused by aquifer overexploitation. The thick surficial quaternary aquifers defined and fed by the 
lateral fans have experienced a $200 \mathrm{~m}$ drop in water level. Our results of the subsidence velocity quantified by InSAR for the 2003-2010 period define a spatial correlation between the piezometric gradient of the 1993 groundwater map referred to above. This gap between the water extraction and the terrain results observed implies a time lag between the water table depletion and the subsidence occurring on the surface. The delay can be explained by the current disconnection between surficial waters and the groundwater table, now forming a deep aquifer that delays rainfall recharge. In fact, after the 2012 flood no recharge at all was registered on the aquifer piezometers (CHS, 2014).

In terms of how subsidence could affect the flood pattern evolution studied here, it should be noted that the ground sinking defines a considerably lower base level for the drainage network. The drop of up to $60 \mathrm{~cm}$ that took place from 2003 to 2010 for the area between the Bejar Rambla outflow and the upper Viznaga channel (Fig. 9) implies a significantly increased gradient in relation to the Nogalte fan. This would facilitate concentration of the water towards subsidence points, stimulating a change in drainage configuration.

According to the hydrogeological maps (Fig. 11), higher groundwater flow gradients occur towards the depression axis. Soil consolidation related to the reduction of interstitial pressure on fine sediments promoted ground subsidence inducing water concentration and channelling towards the most depressed points. This area coincides with the NogalteViznaga connecting corridor, which was revealed as an active floodway during the last flash flood. As a result, a better connection was facilitated between the previously endorheic area and the artificial Viznaga channel. A link between what has been, until the present, an endorheic depression and the Guadalentín River downstream needs to be considered, and subsequently the transformation of the former palustrine configuration into an organized fluvial axial floodway for the depression.

Management of alluvial fan floods in semi-arid areas is extremely complex. Despite their apparent inactivity, ephemeral streams and alluvial fans are fragile systems, but precisely for this reason they enter a metastable phase during those long periods with minor local events, storing potential energy capable of triggering catastrophic changes during extreme events.

After a catastrophic flash flood like the one analysed in this case study, there is increased social pressure for the construction of flood defences. Engineering work may be needed to protect certain reaches, but should always be considered after first assessing the side effects it may generate. Management interventions usually serve to maintain sediment budget deficits (Wishart et al., 2008) and as a result delay the benefits of natural morphological adjustments. Recognition of overall catchment processes in the long term is required rather than reacting in the short term at reach scale, a result of the human tendency to resist natural channel changes (Kondolf and Pie- gay, 2002). The best way of controlling erosion is to promote sedimentation in favourable incipient deposit sites (Schumm, 1977).

\section{Conclusions}

The flash flood event analysed is characterized by short duration and clear water discharge, with hardly any bedload input. This can be attributed first to its torrential character as an event of high rainfall intensity but short duration that promoted rapid surface runoff, as it occurred at the end of the summer drought and with no previous soil humidity. In addition, the net loss of solid load produced by intense in-channel gravel mining needs to be taken seriously into account. A major gap exists in managing flood impacts on these Mediterranean areas due to the lack of solid discharge data (Poesen and Hooke, 1997). The long-term impact of such events needs to be considered, especially as their time-space occurrence does not allow immediate manifestation of their hidden but severe effects.

However, one of the most dangerous consequences of the anthropic factors leading to widespread system instability may be ground subsidence from aquifer overexploitation, due to its imperceptible but retarded character. Compaction of the special clays' material together with sustentation loss due to groundwater extraction undoubtedly favours subsidence, but this effect is neither uniform nor immediate in this region. The metric-scale ground subsidence that has been detected affects the stream base levels, promoting entrenchment and displacement upstream of an erosive wave. The base level drop can severely modify the drainage pattern, erosion and sedimentation areas.

As already discussed, flood regulation by upstream dam construction and stream channelization may restrict fan connectivity with its feeding river, and facilitates the lowering of the water table and related ground subsidence. Land planning at watershed level is essential together with an extensive local information campaign stating present and future terrain conditions and their management implications.

Our analysis suggests the existence of metastable ground conditions in the case study area resulting from a time lag in the manifestation of subsidence as an effect of groundwater extraction, implying significant consequences for the management of this land area, naturally arid but exposed to strong anthropogenic pressure. It should be noted that the impacts described here may be masked and not manifested for long periods of time, until they are triggered by the occurrence of an event of catastrophic magnitude.

\section{Data availability}

Lidar data, river profiles and aerial images of the study area are available at http://iderm.imida.es/iderm/. Channel measurements will be deposited at an approved site in the UAM 
repository (currently under negotiation). ENVISAT data are supplied by the European Space Agency (ESA) at https: //earth.esa.int/web/guest/data-access.

Author contributions. J. A. Ortega-Becerril and G. Garzón designed the fieldwork and recorded all the data related to river morphology, impacts of gravel quarries and flood effects. M. Béjar and J. J. Martínez-Diaz developed the model and obtained the data from InSAR and performed the simulations. J. A. Ortega-Becerril prepared the manuscript with contributions from all co-authors.

Acknowledgements. The authors would like to thank Pepe Murcia and Juan A. López Martín from Lorca, for their support and assistance during fieldwork. We would like to thank X. RodriguezLloveras and the anonymous referee for their helpful comments and for their constructive suggestions. This research was partially funded by projects CGL 2011-23857, ESP2013-47780-C2-2-R and CGL2013-47412-C2-1-P (Spanish Ministry of Economy and Competitiveness). Our thanks is also given to the European Space Agency (ESA) for providing the ENVISAT data (project C1P.9044). GMT software was used to prepare some of the figures.

Edited by: P. Tarolli

Reviewed by: X. Rodriguez-Lloveras and one anonymous referee

\section{References}

Ayala-Carcedo, J. F. and Olcina, J.: Riesgos Naturales, Ariel Ciencia, 1512 pp., 2002.

Barredo, J. J.: Major flood disasters in Europe: 1950-2005, Nat. Hazards, 42, 125-148, 2007.

Benito, G., Machado, M. J., and Lloveras, X. R.: Cómo un evento "moderado" puede causar un impacto extremo. Enseñanza de las Ciencias de la Tierra, 20, 301-304, 2012.

Berardino, P., Fornaro, G., Lanari, R., and Sansosti, E.: A new algorithm for surface deformation monitoring based on small baseline differential SAR interferograms, IEEE Trans. Geosci. Remote Sens., 40, 2375-2383, doi:10.1109/TGRS.2002.803792, 2002.

Boni, R., Herrera, G., Meisina, C., Notti, D., Bejar-Pizarro, M., Zucca, F., Gonzalez, P., Mimmo, R., Roberto. T., FernandezMerodo, J., Mulas, J., Aragón, R., Guardiola, C., and Mora, O.: Twenty-year advanced DInSar analysis of severe land subsidence: the Alto Guadalentin Basin (Spain) case study, Eng. Geol., 198, 40-52, doi:10.1016/j.enggeo.2015.08.014, 2016.

Bull, L. J., Kirkby, M. J., Shannon, J., and Hooke, J. M.: The impact of rainstorms on floods in ephemeral channels in southeast Spain, Catena, 38, 191-209, doi:10.1016/S03418162(99)00071-5, 1999.

Calmel-Avila, M., Silva, P. G., Bardaji, T., Goy, J. L., and Zazo, C.: Variations climatiques et morphogenèse holocène dans le bassin du Guadalentín, région de Murcie, sud-est espagnol, XVIII Colloque International de Climatologie, Gênes, 7-11 Septembre, 39-142, 2005.
Capel Molina, J.: Génesis de las inundaciones de Octubre de 1973 en el Sureste de la Península Ibérica, Cuadernos Geográficos, 4, 149-166, 1974.

Cartomur-IDERM: Spatial data infrastructure of the Murcia Region, http://www.iderm.es/, last access: 3 March 2016.

CHS: Análisis piezómetrico, histórico y de los últimos 25 años (1990-2014), de las masas de agua subterráneas de la demarcación hidrográfica de Segura, Confederación Hidrográfica del Segura, Technical report (unpublished), 2014.

Conesa-García, C.: Torrential flow frequency and morphological adjustments of ephemeral channel in south-east Spain, in: River Geomorphology, edited by: Hickin, E., John Wiley \& Sons, Chichester, 169-192, 1995.

Conesa-García, C. and Alvarez, Y.: Propuesta metodolológica para la delimitación de areas inundables y la estimación de usos afectados en sistemas de drenaje efimero, Nimbus, 11-12, 107-127, 2003.

Costa, J. E. and O'Connor, J. E.: Geomorphically effective floods, in: Natural and anthropogenic influences in fluvial geomorphology, edited by: Costa, J. E., Miller, A. J., Potter, K. W., and Wilcock, P. R., American Geophysical Union, doi:10.1029/GM089p0045, 1995.

Farr, T. G. and Kobrick, M.: Shuttle Radar Topography Mission produces a wealth of data, Amer. Geophys. Union Eos., 81, 583$585,2000$.

Gil Meseguer, E., Pérez Morales, A., and Gómez Espín, J. M.: Precipitaciones y avenidas del 28 de Septiembre de 2012 en el cuadrante Suroccidental de la Cuenca de Segura (Municipios de Lorca, Puerto Lumbreras y Pulpí), Papeles de Geografía, 55-56, 75-94, 2012.

Gómez-Espín, J. M.: Aprovechamiento integral del agua en la Rambla de Nogalte (Puerto Lumbreras - Murcia), Universidad de Murcia, Murcia, 2004.

González, P. J. and Fernández, J.: Drought-driven transient aquifer compaction imaged using multi-temporal satellite radar interferometry, Geology, 39, 551-554, doi:10.1130/G31900.1, 2011.

Heras, R.: Estudio de máximas crecidas de la zona de AlicanteAlmería y Málaga y de las lluvias torrenciales de Octubre de 1973, Memorias Centro Est. Hidrográficos (Diciembre), Madrid, 1973.

Hooke, J. M. and Mant, J. M.: Geomorphological impacts of a flood event on ephemeral channels in SE Spain, Geomorphology, 34, 163-180, doi:10.1016/S0169-555X(00)00005-2, 2000.

Hooke, J. M., Brookes, C. J., Duane, W., and Mant, J. M.: A simulation model of morphological, vegetation and sediment changes in ephemeral streams, Earth Surf. Proc. Land., 30, 845-866, doi:10.1002/esp.1195, 2005

Hooper, A.: A multi-temporal InSARmethod incorporating both persistent scatterer and small baseline approaches, Geophys. Res. Lett., 35, L16302, doi:10.1029/2008GL034654, 2008.

IGME: Proyecto para la Investigación de la cuenca Baja del Segura, Technical report (Unpublished), 1975.

IGME: Mapa geológico de España 1:50.000. Hoja no 975, Puerto Lumbreras, 2009.

Kondolf, G. M.: Hungry water: effects of dams and gravel mining on river channels, Environ. Manage., 21, 533-551, 1997.

Kondolf, G. M. and Piegay, H.: Channel response to increased and decreased bedload supply from land use change: con- 
trasts between two catchments, Geomorphology, 45, 35-51, doi:10.1016/S0169-555X(01)00188-X, 2002.

Larouzière, D., Bolze, J., Bordet, P., Hernández, J., Montenat, C., and Ott D'Estevou, P.: The betic segment of the lithospheric Transalboran Shear Zone during the Late Miocene, Tectonophysics, 152, 41-52, doi:10.1016/0040-1951(88)90028-5, 1988.

López-Bermúdez, F. and Gutiérrez, D.: Descripción y experiencias de la avenida e inundación de octubre de 1982 en la Cuenca del Segura, Estudios Geográficos, 44, 87-100, 1983.

López-Bermúdez, F., Conesa-Gacía, C., and Alonso-Sarria, F.: Floods: magnitude and frequency in ephemeral streams of the Spanish Mediterranean Region, in: Dryland rivers: hydrology and geomorphology of semi-arid channels, edited by: Bull, L. J. and Kirkby, M. J., Wiley, Chichester, 2002.

Marchi, L., Borga, M., Preciso, E., and Gaume, E.: Characterisation of selected extreme flash floods in Europe and implications for flood risk management, J. Hydrol., 394, 118-133, 2010.

Martin-Vide, J. P., Ferrer-Boix, C., and Ollero, A.: Incision due to gravel mining: Modeling a case study from the Gallego River, Spain, Geomorphology, 117, 261-271, doi:10.1016/j.geomorph.2009.01.019, 2010.

Michaelides, K. and Singer, M. B.: Impact of coarse sediment supply from hillslopes to the channel in runoff-dominated, dryland fluvial systems, J. Geophys. Res.-Earth, 119, 1205-1221, doi:10.1002/2013JF002959, 2014.

Navarro-Hervás, F.: Morfoestructura y comportamiento hídrico de la rambla de Nogalte. Actas IX Coloquio de geografía, T.I, Asociación de Geógrafos Españoles, Murcia, 1985.

Ortega, J. A.: Cartografía de avenidas e inundaciones en el alto y bajo Guadalentín, in: Estudio y cartografía de los peligros geológicos del alto y bajo Guadalentín de la Región de Murcia, edited by: Mulas, J. and Clemente, A. A., IGME, Spanish Geological Survey Technical Report, not published, 2007.

Ortega, J. A. and Garzón, G.: Geomorphological and sedimentological analysis of flash-flood deposits. The case of the 1997 Rivillas flood (Spain), Geomorphology, 112, 1-14, doi:10.1016/j.geomorph.2009.05.004, 2009.

Ortega, J. A., Garzón, G., García, J. C., and Rodriguez, A.: Funcionamiento de la rambla de Nogalte (Murcia) durante avenidas. Implicaciones para la cartografía de peligrosidad por riesgo de avenidas, in: Advances in soil erosion studies, edited by: Romero, A., Belmonte, F., Alonso, F., and Lopez-Bermudez, F., Universidad de Murcia, 485-488, 2009.

Ortega, J. A., Razola, L., and Garzón, G.: Recent human impacts and change in dynamics and morphology of ephemeral rivers, Nat. Hazards Earth Syst. Sci., 14, 713-730, doi:10.5194/nhess14-713-2014, 2014.

Perez, A. and Gil, S.: La avenida de 22 de octubre de 1049 en la Cuenca del Segura, Estudios Geográficos, 73, 163-187, 2012.

Pernia, J. M., Del Val, J., Simon, A., Boquera, J., and Artaiz, C.: Mapas previsores de riesgos en núcleos urbanos de la Comunidad de Murcia, IGME, 7-16, 1987.

Poesen, J. W. A. and Hooke, J. M.: Erosion, flooding and channel management in Mediterranean environments of southern Europe, Prog. Phys. Geog., 21, 157-199, doi:10.1177/030913339702100201, 1997.
Rice, S.: Which tributaries disrupt downstream fining along gravelbed rivers?, Geomorphology, 22, 39-56, doi:10.1016/S0169555X(97)00052-4, 1998.

Rigo, A., Béjar, M., and Martinez-Diaz, J. J.: Monitoring of Guadalentín valley (southern Spain) through a fast SAR Interferometry method, J. Appl. Geophys., 91, 39-48, doi:10.1016/j.jappgeo.2013.02.001, 2013.

Schumm, S. A.: Geomorphic thresholds and complex response of drainage systems, in: Fluvial Geomorphology, SUNY Binghamton Publications in Geomorphology, edited by: Morisawa, M., Binghamton, NY, 299-310, 1973.

Schumm, S. A.: The Fluvial System, John Wiley and Sons, New York, 1977.

Schumm, S. A., Harvey, M. D., and Watson, C. C.: Incised Channels: Morphology, Dynamics, and Control, Water Resources Publications, Littleton, CO, 1984.

Scott, K. M.: Scour and fill in Tujunga Wash, a fanhead valley in urban southern California. 1969, U.S Geological Survey Professional Paper 732-B, 1973.

Segura-Beltrán, F. and Sanchis-Ibor, C.: Assessment of channel changes in a Mediterranean ephemeral stream since the early twentieth century. The Rambla de Cervera, Eastern Spain, Geomorphology, 201, 199-214, doi:10.1016/j.geomorph.2013.06.021, 2013.

Silva, P. G., Goy, J. L., Somoza, L., Zazo, C., and Bardaji, T.: Landscape response to strike-slip faulting linked to collisional settings: Quaternary tectonics and basin formation in the Eastern Betics, southeastern Spain, Tectonophysics, 224, 289-303, doi:10.1016/0040-1951(93)90034-H, 1993a.

Silva, P. G., Bardají, T., Calmel-Avila, M., Goy, J. L., and Zazo, C.: Transition from alluvial to fluvial systems in the Guadalentín Depression (SE Spain) during the Holocene: Lorca Fan versus Guadalentín River, Geomorphology, 100, 140-153, doi:10.1016/j.geomorph.2007.10.023, 2008.

Singer, M. B. and Michaelides, K.: How is topographic simplicity maintained in ephemeral dryland channels?, Geology, 42, 10911094, doi:10.1130/G36267.1, 2014.

Surian, N., Righini, M., Lucía, A., Nardi, L., Amponsah, W., Benvenuti, M., Borga, M., Cavalli, M., Comiti, F., Marchi, L., Rinaldi, M., and Viero, A.: Channel response to extreme floods: Insights on controlling factors from six mountain rivers in northern Apennines, Italy, Geomorphology, 272, 78-91, doi:10.1016/j.geomorph.2016.02.002, 2016.

Wishart, D., Warburton, J., and Bracken, L.: Gravel extraction and planform change in a wandering gravel-bed river: The River Wear, Northern England, Geomorphology, 94, 131-152, doi:10.1016/j.geomorph.2007.05.003, 2008.

Wohl, E. E.: Inland Flood Hazards, Cambridge Univ. Press, Cambridge, 498 pp., 2000. 